\section{Occurrence of the Cyclopoid, Herrmannella rostrata Canu, in Cardium edule}

WHILsT examining Cardium edule isolated in bowls and obtained from Morecambe Bay, Laneashire, Prof. Orton found an abundance of copepods and gave them to me for examination.

The copepod proved to be Herrmannella rostrata Canu, ${ }^{1}$ one of the Lichomolgidæ leading a semiparasitic existence in the cockle. When the cockles were opened separately in finger-bowls in the laboratory many of the copepods were clearly seen to leave their hosts ; they appeared to be distributed throughout the mantle cavity but showed a tendency to congregate round the siphons. Tow-nettings from gulleys on the cockle beds in Morecambe Bay revealed a number of Herrmannella swimming actively in the sea-water amongst various Calanoids and other planktonic material. Males and females with and without egg sacs were seen both in the cockle and swimming freely.

Canu records Hermannella rostrata from the mantle cavities of Cardium edule L., Mactra stultorum L., and Pecten opercularis $\mathrm{L}$., from the French coast, but there does not appear to be any record of its being found in British waters. As it is so very abundant in Cardium from Morecambe Bay, it seems unlikely that it is of merely local occurrence, but possibly has been mistaken for Lichomolgus agilis (Leydig), a species which it closely resembles and which has been recorded from Cardium from many localities and from Lancashire by Thompson. ${ }^{2}$ Sars, Canu, and many other writers ${ }^{3}$ record $L$. agilis only from the Nudibranchiata.

Dept. of Oceanography,

$$
\text { J. H. Fraser. }
$$

University of Liverpool, July 9.

1 Canu, E., “Les Copépods marins du Boulonnais", Bulletin Scientifique de la France et de la Belgique, Tome xxiti., 1891.

2 Thompson, I. C., "Revised Report on the Copepoda of Liverpool Bay". Trans. Liverpool Biological Soc., vol. vii., 1893 .

"Copépods du Boulonnais", Travaux du Laboratoire de Zoologie Maritime de Wimereux-Ambleteuse, Tome vi., Lille, 1892.

\section{Habits of the Toad, Ceratophrys}

A Mushap which throws additional light on the voracious habits of the South American toad Cera. tophrys deserves to be put on record. Four of these creatures were received here at the end of June and at the same time two small alligators. When they came, only one vivarium was ready for use, and for a week the toads and alligators shared accommodation in it. They appeared to ignore one another and to be perfectly content. The alligators spent much of the time basking on the top of a small wooden penthouse or immersed in the water trough: the toads dug themselves comfortable burrows and were soon effectively concealed. Both took the food that was offered to them, the toads showing an appetite for the common frog and the alligators for a diet of beef and worms.

Meanwhile a new vivarium was prepared. But when the day came to transfer the alligators to it, it was found that one of them had completely vanished during the previous night. A tnorough search revealed no trace of the missing animal, and the suspicion grew that one of the toads was responsible for its disappearance. On the pampas they are reputed to steal chickens, and Gadow reports an instance of cannibalism even, on the part of one of a pair sent to him by a friend (cf. Cambridge Natural History-" Amphibia and Reptiles ", p. 217). The four toads in this case were subjected to a screening examination with $\mathrm{X}$-rays, and in one of them a large dark shadow distinctly disclosed the presence of the missing alligator.

The length of the alligator was 11 in. over all (head
2 in., body 3 in., tail 6 in.). Its maximum breadth was $1 \frac{1}{4}$ in. The corresponding dimensions of the toad are: length 6 in., maximum breadth $3 \frac{1}{2}$ in.

It remains to be said that the toad is digesting its unusual meal with the utmost complacency.

Zoology Department, University of Glasgow.

\section{The Andean Eruption and Sunset and Sunrise Glows in South Africa}

THE first sunset glow due to volcanic dust from the Andean eruption was seen in Cape Town on April 21. The glow, which was of remarkable intensity, started about fifteen minutes after sunset and lasted fully an hour, the colour being a deep fiery red. There were many inquiries that evening at the Cape Times office and at the Central Fire Station whether a large fire was raging in the suburbs ; there were also numerous telephonic inquiries at the Royal Observatory as to the eause of the phenomenon. I therefore gave a statement to the Cape Times, which appeared in the following morning's paper, attributing the phenomenon to volcanic dust from the Andean eruption, and anticipating that it would be followed by sunrise and sunset glows for several weeks.

The glows have continued to be visible in Cape Town up to the present time, eight weeks since the appearance of the first glow, with varying but on the whole decreasing intensity. None, however, has been so striking as the sunset glow on the evening of April 21 and the sunrise glow the following morning.

$I$ have collected some information as to the region over which the glows have been visible. It appears that they have been generally observed throughout the Union of South Africa and the Bechuanaland and Basutoland Protectorates. The effects appear to have been even more striking in the clear air of the Karroo and the high veldt than here. At Mafeking, one month after the appearance of the first glow, a trustworthy observer stated that the glow was of a fire-red colour stretching right across the sky, even long after darkness.

The speed of the easterly moving current of air which carried the volcanic dust across from South America would appear to be about twelve miles per hour.

H. SPEnCER Jones

Royal Observatory,

(H.M. Astronomer).

Cape of Good Hope, July 14.

\section{Aurignacian Flint Implements from Raised- Beaches underlying the Brown Boulder Clay}

Recentuy, in conjunction with Mr. J. Reid Moir, I recorded my discovery within the Thames valley of a Middle Mousterian occupation-floor overlain by gravel and brickearth ( $70 \mathrm{ft}$. above $0 . D$.) and post. dating the formation of the Coombe Rock. ${ }^{1}$

I have since been engaged in a series of excavations in the estuarine graveis at Kirmington (90 ft. above O.D.) and to the west of Barton-on-Fumber, Lincolnshire (50 ft. above O.D.). At both these sites the Brown Boulder Clay caps the estuarine gravel.

In addition to derived artefacts belonging to earlier periods, these estuarine gravels contain implements of Aurignacian age likewise exhibiting a rolled condition.

These specimens will be described before the Society of Antiquaries of London in November next.

30 Southwick Street, J. P. T. Burchell.

Hyde Park, W.2.

1 Nature, 130, 95, July 16, 1932.

No. 3277, VoL. 130] 